\title{
INFLUENCE OF RELEVANT FACTORS ON COMPETITIVENESS OF WINE SECTOR OF THE REPUBLIC OF SERBIA
}

\author{
Radivoj Prodanovićl, Svetlana Ignjatijević ${ }^{2}$,Jelena Vapa-Tankosić3 , Ivana Brkić, \\ Siniša Škrbićs, Jovana Gardašević ${ }^{6}$, Miroslav Čavlin ${ }^{7}$ \\ *Corresponding author E-mail: rprodanovic@fimek.edu.rs
}

A R T I C L E I N F O
Original Article
Received: 25 February 2021
Accepted: 01 August 2021
doi:10.5937/ekoPolj2104911P
UDC 339.137.2:663.25(497.11)
Keywords:
competitiveness, wineries, wine,
exports, revealed comparative
adventage

JEL: F12, Q13, Q17

\begin{abstract}
A B S T R A C T
Wine production in the Republic of Serbia has a long tradition and potential for improvement, given the agro-climatic and other conditions. The aim of this paper is to analyze the competitiveness factors of wineries in the Republic of Serbia. The findings show that the wine industry is developing, but its' competitiveness is at a relatively low level. In order to strengthen the competitiveness of the wine sector, it is necessary to define and implement a strategy, which will include activities such as modernization of grape processing technology, new investments and investment in human resources, marketing, winemakers' association and creating a stimulating business climate. Without state support, a significant increase in the competitiveness of wineries cannot be expected. Since interest in wine production has been recently growing, it is to be expected that the wine production, as well as its' export will increase, thus achieving significantly greater economic effects.
\end{abstract}

(C) 2021 EA. All rights reserved.

1 Radivoj Prodanović, Associate Professor, Faculty of Economics and Engineering Management in Novi Sad, Cvecarska Street no. 2, 21000 Novi Sad, Serbia, Phone: +381 21400 484, E-mail: rprodanovic@fimek.edu.rs, ORCID ID: (https://orcid.org/0000-0002-7088-8506)

2 Svetlana Ignjatijević, Associate Professor, Faculty of Economics and Engineering Management in Novi Sad, Cvecarska Street no. 2, 21000 Novi Sad, Serbia, Phone: +381 21 400 484, E-mail: ceca@fimek.edu.rs, ORCID ID: (https://orcid.org/0000-0002-9578-3823)

3 Jelena Vapa-Tankosić, Full Professor, Faculty of Economics and Engineering Management in Novi Sad, Cvecarska Street no. 2, 21000 Novi Sad, Serbia, Phone: +381 21400 484, E-mail: jvapa@fimek.edu.rs, ORCID ID (https://orcid.org/0000-0001-8062-1154)

4 Ivana Brkić, Assistant Professor, Faculty of Economics and Engineering Management in Novi Sad, Cvecarska Street no. 2, 21000 Novi Sad, Serbia, Phone: +381 21400 484, E-mail: ivana.j.milosevic@fimek.edu.rs, ORCID ID (https://orcid.org/0000-0002-5319-7893)

5 Siniša Škrbić, Assistant Professor, Faculty of Economics and Engineering Management in Novi Sad, Cvecarska Street no. 2, 21000 Novi Sad, Serbia, Phone: +381 21400 484, E-mail: skrbic.sinisa@gmail.com, ORCID ID (https://orcid.org/0000-0003-0638-8299)

6 Jovana Gardašević, Assistant Professor, Faculty of Economics and Engineering Management in Novi Sad, Cvecarska Street no. 2, 21000 Novi Sad, Serbia, Phone: +381 21400 484, E-mail: j.gardasevic@fimek.edu.rs, ORCID ID (https://orcid.org/0000-0002-3239-2083)

7 Miroslav Čavlin, Full Professor, Faculty of Economics and Engineering Management in Novi Sad, Cvecarska Street no. 2, 21000 Novi Sad, Serbia, Phone: +381 21400 484, E-mail: cmiros@gmail.com, ORCID ID (https://orcid.org/0000-0001-7465-7441) 


\section{Introduction}

The wine industry in the Republic of Serbia is an important economic activity, especially in recent times, given that it shows the potential to encourage the development of agriculture and rural areas, on a sustainable basis.

Wine production and marketing can improve agriculture, provide producers with a more favorable economic position, and consumers satisfaction, because these high-quality products are in demand (Espejel et al., 2008). Wine production in Serbia is at a relatively low level, which annually amounts to about 37.6 million liters, but an optimistic trend of growth has been registered in the recent years (Vlahović et al., 2017). Processing capacities are largely unused, and the optimism is instilled by the fact that more small wineries have been built in recent times, which are trying to position themselves on the market by offering quality and high quality wines with geographical origin.

Strengthening the capacity of the wine industry, i.e. the competitiveness of Serbian wines, has only in recent years become a subject of interest, both for agricultural structures and participants in the value chain, as well as for researchers (Prodanović et al., 2020).

Competitiveness is an indicator of business success, and refers to the possibility of selling products and services in a particular market without difficulty. The competitiveness is practically conditioned by the productivity and can be increased by applying new knowledge, technologies, investments and increased efficiency (Ignjatijević et al., 2018).

The market of the Republic of Serbia is characterized by the offer of domestic as well as imported wines, since the domestic wines cannot meet the growing demand. The growing supply and demand of wine imposes the task of creating and implementing a strategy to strengthen the competitive position of domestic wineries, which is an important prerequisite for strengthening wine capacity.

The improvement of the market position of domestic wines, i.e. the growth of the competitiveness of wine capacities, can be realized by increasing the quality of input raw materials and the processing technology itself. In this regard, we emphasize that there is a trend of modernizing the technology of grape and wine production, the introduction of quality vine cuttings and the purchase of modern equipment in wineries. This trend should be maintained aiming to change the structure of wine production with agricultural policy measures, which will be based on scientific principles and new technologies.

Raising the competitiveness of the wine industry would improve the market position of economic entities and individual agricultural holdings, which are engaged in the production and marketing of wine. For the Republic of Serbia, as well as for all countries with relatively small market potential, the international market is a real indicator of competitiveness, because it is much larger than the domestic market and thus crucial to their development. Therefore, the analysis of the competitiveness of domestic wines relies on imports and exports. 


\section{Methodology and data sources}

The research is based on a review of scientific and professional literature, and uses general scientific methods, while as specific methods and tools we emphasize relevant economic indicators and compound annual growth rate (CAGR).

For the needs of the analysis of the competitiveness of domestic wine capacities, the methodological solution "Porter's diamond model" is used, where the general business conditions are specially analyzed. Porter discusses the issue of competitiveness by posing the question of the reasons for the international success of companies located in certain countries and regions (Porter, 1990). According to Porter, the characteristics of the environment in which companies operate represent the most important deciding factors of competitiveness:

- factor conditions;

- strategy, structure and rivalry;

- demand conditions;

- related supporting industries.

The research used a database on international trade in wine. The data were taken from the Republic Statistical Office, the database of the World Trade Center and include tenyear data series, starting in 2010.

\section{Aim of the paper}

The aim of this paper is to investigate all relevant factors that determine the level of competitiveness of the wine sector of the Republic of Serbia. The main research question is as follows: is the competitiveness of the wine sector of the Republic of Serbia satisfactory, i.e. is there a possibility of strengthening the competitiveness of domestic wines, as a basic precondition for strengthening its' production capacity?

Therefore, the research of the competitive position of wine producers from the Republic of Serbia aims to define the preconditions for formulating a successful strategy for improving competitiveness, ie strengthening the capacity of the wine industry.

\section{General conditions for the growth of the competitiveness of the wine industry of Serbia}

Wine production in the Republic of Serbia is mainly based on family wineries of small and medium capacity. The main reasons for the relative lag of this sector, which determine the low competitiveness and productivity of grape producers and processors, are the small areas under vineyards, ie the lack of economies of scale, modern equipment and technology (Prodanović et al., 2020). Wineries with a larger volume of production also have a higher level of competitiveness (economies of scale). In addition to professional education, wine producers have at their disposal counseling, seminars and other types of education. Most small producers hire family members to carry out all business 
activities. The technology of grape processing and wine production is gradually being improved, quality equipment for processing and storage is being procured (Jakšić et al., 2015), which contributes to the growth of competitiveness. Still, one of the main reasons for the slow growth of the wine industry is the modest investment in people, i.e. the orientation towards investments in the physical factors of production. Research shows that an increasing number of wineries use state subsidies, and invest primarily in the purchase of new machines and equipment. Given the low level of production and the current state of equipment of wineries, on the other hand, growing demand, the need for significant investments is expressed. Financing conditions have not changed significantly and winemakers are of the opinion that the capital is still unavailable due to the high cost of capital and complicated loan approval procedures.

In the period after 2000, with the opening of the market, the preconditions for strengthening competitiveness have been created. The opening of the market was supposed to encourage the application of innovations and new technologies in production. However, most producers, pressed by financial difficulties and lack of working capital, did not invest significantly in new technologies. The current situation of the wine industry is tolerable (Denda and Denda, 2016; Prodanović et al., 2020), and a significant improvement in the production process is expected.

In the last two decades, the wine sector has achieved a noticeable growth trend in demand, thanks to changes in the habits of consumers, who increasingly consume quality wines, but also thanks to promotion through specialized fairs and traditional events (Pivac et al., 2015).

In a study by Vlahović et al. (2017) almost half of the respondents (45\%) do not differentiate between domestic and foreign wines, i.e. they consume both equally. The level of demand for domestic wines is not stimulating enough to increase production. As domestic wines have has a dynamic introduction of on the market only in the last two decades, it is clear that we cannot talk about products that have a strong position in the minds of consumers.

Many wine producers enter the market independently, which is why they do not achieve adequate sales prices, nor do they ensure the security of placement, which cannot, as a rule, result in high efficiency. In this regard, the association of wineries in cooperatives is imposed as an economically rational activity. Associations should provide stimulation of wine production, influence the exchange of ideas and experiences, cooperation with state institutions, in one word, to ensure the strengthening of competitiveness (Prodanović et al., 2020; Cvijanović and Ignjatijević, 2020). Within clusters, cooperatives and associations of producers, the existing competitive advantages (labor and natural resources) would be better used, and also cooperation with institutes and other scientific and educational institutions would be more accessible (Paraušić and Cvijanović, 2014; Ignjatijević and Cvijanović, 2017). The association of wineries would enable more effective wine promotion and a better reputation for wineries, which is essential for production growth (Jević et al., 2019). 
The role of the state in increasing the competitiveness of the wine industry is directly related to the policy of economic development, and is reflected primarily in the creation of favorable general conditions for business and proper functioning of the market (Marinković et al., 2016; Cvijanović et al., 2020). Based on that, mutual competition of wine producers on the market in regard to attracting consumers, finding the most efficient production processes and lowering prices, can be organized most efficiently in free market conditions, which guarantee that producers will have equal conditions and the pre-known "rules of the game" (Đurić, 2015). The state should provide equal conditions for all market participants and market laws will accept or reject participants depending on their abilities (Crampton, 2002). The state should build and improve institutions, which will stimulate the growth of competitiveness. The creation of institutions is preceded by legislation, which will clearly define the rules of conduct and clear procedures while building a judicial system, which will enable compliance with these measures, and quickly and effectively sanction their non-compliance. At the same time, domestic rules, which are not in accordance with European (international) regulations and standards, should be harmonized. Given that the legislation and standards are fully harmonized, activities should be focused on innovating the zoning of viticultural production, as well as the proper distribution of budget funds by vineyard areas, respecting the regional location and geographical origin (Pivac, 2012). In this context, measures and instruments of the European Union (hereinafter: EU) Common Agricultural Policy, ie regulations concerning viticultural production and the wine sector, are of primary importance.

We cannot be completely satisfied with the institutional framework and the role of the state in increasing the competitiveness of the wine industry, given that legislation and competent institutions still lack capacities for pursuing more significant actions (Leković, 2016). The new Strategy of Scientific and Technological Development of the Republic of Serbia (2021 - 2025) emphasizes the strengthening of institutions, innovation, knowledge and new technologies, which is a prerequisite for the growth of competitiveness of the economy, and thus the wine industry.

The state should support those productions for whose products there is a demand, such as e.g. production of high quality indigenous wines. The unemployment rate in the Republic of Serbia is relatively high (10.9\% in 2019), especially of young people in rural areas (20.7\% in 2019), which is significantly higher compared to the European Union, where the unemployment rate is $6.4 \%$ (Strategija zapošljavanja u Republici za period od 2021. do 2025). In this context, reducing unemployment through support for specific programs in agriculture, such as grape and wine production, is necessary and completely justified.

\section{Competitiveness factors of wine producers}

The importance of the wine industry in the Republic of Serbia and the analysis of its' competitiveness can be observed through the fact that, in the recent period, it has achieved a mild growth. 
The principle of production efficiency can be equated with competitiveness (Dresch et al., 2018). Wine producers must be trained in regard to production operations, where opportunities to increase productivity and competitiveness are greatest. This increase should be based on the segment of continuous increase of wine quality, improvement of production technology or raising production efficiency. Most of the wine capacities are located within individual agricultural holdings and their strategy of conquering new technologies is crucial for developing competitiveness. Experience shows that in small agricultural holdings, the implementation of new technologies is slow, therefore the incentives are needed (Yigezu et al., 2018).

\section{Technology as a factor in the competitiveness of the wine industry}

Technology should be cited as a key factor in establishing a better competitive position for the wine industry. Namely, the opening of the market led to an increase in competition, but this growth is at the expense of the participation of basic factors, not technology, as is the case in EU countries (Vukajlović and Ćurčić, 2016). It happens exactly that the imported wines with low technology are competitive in the domestic market. The economic climate in the past period did not sufficiently encourage the introduction of new technologies. The Republic of Serbia lags behind technologically, but the interest of medium and large economic entities in the application of new digital technologies has been expressed (USAID, 2019). Also, it points out importance of efficient technology transfer in Serbia for further development (Mosurović Ružičić et al., 2015).

The institutional framework and the role of the state do not encourage the introduction of new technologies to the desired extent. It is necessary to define and implement an appropriate technological strategy, in order to maintain and increase the competitiveness of the wine industry.

Stimulating research and development projects can contribute to strengthening the competitive position of the wine industry, and implies a special role of the state (eg direct subsidies or tax relief), because wineries do not posses enough knowledge for such activities. The state still does not allocate enough funds for research and development. Furthermore, we estimate that the wine industry will not be able to invest significantly in research and development of technologies in the near future, so competitiveness will not increase very much.

\section{Monitoring the so-called discovered comparative advantages in wine production}

«Revealed Comparative Adventage» - RCA represents the ratio of the foreign trade balance and the total volume of trade. The value of this indicator is expressed as a percentage and observed from year to year, shows an increase or decrease in competitiveness (Božić and Nikolić, 2016). For example, in 2010, the foreign trade balance of wine amounted to $-21,274,400.00 \$$, and in 2011 it has decreased to 20,610,200.00 $\$$ and has maintained the decreasing trend during the observed period. It 
is especially indicative that the negative foreign trade balance has significantly decreased in the last two years of the observed period, which represents a positive trend. In 2019, the foreign trade balance of wine amounts to - 9,966,400.00 \$ (Table 1). The value of RCA during the analyzed period shows that compared to $2010(13,176,700 \$)$ there was an increase in exports, and thus the competitiveness of wine in foreign markets.

At the beginning of the observed period (2010-2012), there was a sharp increase in the value of wine exports, and then a decline in exports until 2016, but a disproportionate increase was again recorded in 2017 (Table 1). On the import side, the value has decreased slightly since 2011, when it amounted to almost \$ 38 million, but in 2016, the wine imports have increased again. Despite significantly higher imports compared to exports, the data on the trend of slight growth of wine imports since 2016 is of high concern.

The average value of wine exports from the Republic of Serbia is $\$ 16,688,950$, and imports of $\$ 33,853,400$. Data on foreign trade of wine (Serbia - World) show that in the observed period there was an increase in exports at a rate of $5.65 \%$, and imports at a rate of $-0.96 \%$, i.e. imports recorded a slight decline, which is optimistic. The analysis of the exported quantity of wine indicates further possibilities for export growth.

The price of wine in exports varies and in 2019 averages $\$ 1.55 / 1$, which is significantly higher than the average for the observed period $(\$ 1.36 / 1)$.

Table 1. Foreign trade of wine Serbia - World (2010-2019)

\begin{tabular}{|l|l|l|l|c|c|c|c|}
\hline Year & & Export & Import & $\begin{array}{c}\text { Foreign } \\
\text { trade } \\
\text { balance }\end{array}$ & $\begin{array}{c}\text { Average } \\
\text { export } \\
\text { price } \\
\mathbf{( \$ / k g )}\end{array}$ & $\begin{array}{c}\text { Average } \\
\text { import } \\
\text { price } \\
\mathbf{( \$ / k g )}\end{array}$ & $\begin{array}{c}\text { Coverage } \\
\text { of import } \\
\text { by export } \\
\mathbf{( \% )}\end{array}$ \\
\hline 2010. & Quantity, in t & $11,325.10$ & $28,459.00$ & & & & \\
\hline & Value in 000 USD & $13,176.70$ & $34,451.10$ & $-21,274.4$ & 1.16 & 1.21 & $\mathbf{3 8 , 2 5}$ \\
\hline 2011. & Quantity, in t & $15,419.00$ & $29,959.70$ & & & & \\
\hline & Value in 000 USD & $17,306.60$ & $37,916.80$ & $-20,610.2$ & 1.12 & 1.26 & $\mathbf{4 5 , 6 4}$ \\
\hline 2012. & Quantity, in t & $23,510.30$ & $30,803.40$ & & & & \\
\hline & Value in 000 USD & $21,209.90$ & $35,333.30$ & $-14,123.4$ & 0.90 & 1.15 & $\mathbf{6 0 , 0 2}$ \\
\hline 2013. & Quantity, in t & $12,469.50$ & $24,574.60$ & & & & \\
\hline 2014. & Quantity, in t & $11,976.40$ & 25.788 .70 & & & & \\
\hline & Value in 000 USD & $17,026.50$ & $33,433.50$ & $-16,407.0$ & 1.42 & 1.30 & $\mathbf{5 0 , 9 3}$ \\
\hline 2015. & Quantity, in t & $10,595.30$ & $25,055.50$ & & & & \\
\hline & Value in 000 USD & $14,297.30$ & $28,351.20$ & $-14,053.9$ & 1.35 & 1,13 & $\mathbf{5 0 , 4 3}$ \\
\hline $\mathbf{2 0 1 6 .}$ & Quantity, in t & $9,881.00$ & $29,395.20$ & & & & \\
\hline & Value in 000 USD & $14,922,90$ & $30,265.60$ & $-15,342.7$ & 1.51 & 1.03 & $\mathbf{4 9 , 3 1}$ \\
\hline
\end{tabular}




\begin{tabular}{|l|l|c|c|c|c|c|c|}
\hline Year & & Export & Import & $\begin{array}{c}\text { Foreign } \\
\text { trade } \\
\text { balance }\end{array}$ & $\begin{array}{c}\text { Average } \\
\text { export } \\
\text { price } \\
\mathbf{( \$ / k g )}\end{array}$ & $\begin{array}{c}\text { Average } \\
\text { import } \\
\text { price } \\
\mathbf{( \$ / k g )}\end{array}$ & $\begin{array}{c}\text { Coverage } \\
\text { of import } \\
\text { by export } \\
\mathbf{( \% )}\end{array}$ \\
\hline 2017. & Quantity, in t & $12,184.50$ & $26,781.40$ & & & & \\
\hline & Value in 000 USD & $19,465,60$ & $30,771.80$ & $-11,306.2$ & 1.60 & 1.15 & $\mathbf{6 3 , 2 6}$ \\
\hline 2018. & Quantity, in t & $12,769.60$ & $22,465.40$ & & & & \\
\hline & Value in 000 USD & $21,228,10$ & $31,838.90$ & $-10,610.8$ & 1.66 & 1.42 & $\mathbf{6 6 , 6 7}$ \\
\hline 2019. & Quantity, in t & $13,990.60$ & $22,263.50$ & & & & \\
\hline & Value in 000 USD & $21,610,00$ & $31,576.40$ & $-9,966,4$ & 1.55 & 1.42 & $\mathbf{6 8 , 4 4}$ \\
\hline
\end{tabular}

Source: Statistical Office of the Republic of Serbia

During the entire period that has been analyzed, the Republic of Serbia imports significantly more wine than it exports. In 2019, 22,263,500 liters were imported, for which $\$ 31,57640$ has been spent. The import price of a liter of wine was $\$ 1.42 / 1$, so it can be concluded that we import wine at a slightly lower price compared to the export price. The lower import price is the result of a lower share of technology (added value) in the selling price. This implies that domestic wine is potentially competitive, but it should diversify the offer, enhance marketing activities (promotion, packaging, etc.), in order to achieve an even higher price in exports. Aguglia and Salvioni (2010) point out that the export-oriented producers should focus on direct marketing, thus achieving higher prices.

The coverage of imports by exports is at a relatively low level. The highest coverage rate was recorded in 2018 and 2019, when exports were covered with $66.67 \%$ and $68.44 \%$, respectively. In other words, the import quantities of wine are significantly higher in relation to the exported quantities, which indicate the non-use of potentials and resources at our disposal, but also other factors, such as lack of branding and adequate marketing strategy.

In 2019, the Republic of Serbia achieved a record value in wine exports of 21.61 million dollars (Table 1). Compared to 2008, the value of exports has doubled. The growth trend of wine exports was also recorded in 2020, so a new annual record can be expected (Zdravković, 2020).

The import of wine to the Republic of Serbia was worth 31.5 million dollars in 2019 and was slightly lower than in 2008 (\$32.4 million) (SORS, https://data.stat.gov.rs).

The deficit in the foreign trade balance of wine can be partially reduced based on the increase in production and exports of small wineries. The wine tourism has the potential to offer indigenous wines and local specialties, and can contribute to the recognition of the wine region and indirectly to the improvement of the wine sector (Erdelji and Lajko, 2015; Pivac et al., 2015). Wine routes have been designed for effective promotion and easier sale of wine (Brščić et al., 2010; Jovanović et al., 2015). The wine route consists 
of natural beauties, cultural and historical sights, traditions and peculiarities of the wine-growing area (Pivac, 2008).

The SAA (Stabilization and Association Agreement) and CEFTA (Central European Free Trade Association) agreements enabled the placement of wine on the European market, but due to the long-standing crisis in the viticulture and winemaking sector, the Republic of Serbia cannot respond to the demands of these markets.

The analysis of the data shows that the total wine turnover of the Republic of Serbia with the EU averages $\$ 10,323,860.00$ per year, of which exports account for $27.00 \%$, or $\$ 2,786,990.00$ (Table 2). We can conclude that the EU is an important trade partner when it comes to wine and that the Republic of Serbia has an extremely negative trade balance, which is probably the result of imports of high quality wines, while on the other hand, it exports lower quality wines with a smaller share of technology.

The Republic of Serbia had the largest volume of wine trade within the CEFTA market, where the majority of import wine originates (Ministarstvo poljoprivrede, šumarstva i vodoprivrede - MPŠV RS, 2019).

According to the SORS for the period 2012-2018, a positive foreign trade balance was achieved with the countries of the EU in terms of quantities $(798,1001)$, but a negative average annual balance in terms of value $(3,384,700$ euros) of wine. It is indicative that the average export to the EU market in the observed period was 2,733,000 liters (with an average annual value of 1,935,560 euros) and the average annual import was 1,935,000 liters (with an average annual value of 5,167,260 euros) (SORS, 2012-2018).

The export of wine to the EU market is regulated by quotas in the SAA and is set at the level of 63,000 hectoliters per year, which is currently above the capabilities of the Republic of Serbia (Erdelji and Lajko, 2015). This speaks in favor of the fact that domestic wines do not contain additional value, and as such cannot achieve a high price.

Table 2. Foreign trade of wine Serbia - EU (2012-2019)

\begin{tabular}{|l|l|c|l|}
\hline Year & & \multicolumn{1}{|c|}{ Export } & \multicolumn{1}{c|}{ Import } \\
\hline $\mathbf{2 0 1 2 .}$ & Quantity, in t & $14,104.50$ & $2,248.20$ \\
\hline & Value in 000 USD & $8,432.90$ & $7,480.60$ \\
\hline $\mathbf{2 0 1 3 .}$ & Quantity, in t & $2,062.20$ & $2,013.10$ \\
\hline & Value in 000 USD & $1,929.00$ & $7,997.10$ \\
\hline $\mathbf{2 0 1 4 .}$ & Quantity, in t & 572.10 & $1,986.40$ \\
\hline & Value in 000 USD & $1,456.20$ & $7,065.40$ \\
\hline $\mathbf{2 0 1 5 .}$ & Quantity, in t & 603.80 & $2,009.80$ \\
\hline & Value in 000 USD & 1.457 .90 & $6,312.20$ \\
\hline $\mathbf{2 0 1 6 .}$ & Quantity, in t & 485.70 & $1,933.50$ \\
\hline & Value in 000 USD & $1,373.90$ & $6,326.30$ \\
\hline $\mathbf{2 0 1 7 .}$ & Quantity, in t & 899.10 & $1,767.80$ \\
\hline
\end{tabular}




\begin{tabular}{|l|l|l|l|}
\hline Year & & \multicolumn{1}{|c|}{ Export } & \multicolumn{1}{c|}{ Import } \\
\hline & Value in 000 USD & $1,777.10$ & $6,512.20$ \\
\hline $\mathbf{2 0 1 8 .}$ & Quantity, in t & $1,410.70$ & $1,949.20$ \\
\hline & Value in 000 USD & $2,051.50$ & $8,342.20$ \\
\hline $\mathbf{2 0 1 9 .}$ & Quantity, in t & $1,496.70$ & $3,074.70$ \\
\hline & Value in 000 USD & $2,488.30$ & $10,259.00$ \\
\hline
\end{tabular}

Source: SORS

The basic assumptions of product competitiveness are (Živkov et al., 2012):

- If the value of exports of a product is significant or higher than its'competitors', there is potential for growth in the competitiveness of that product;

- If the trend of export growth is faster than from its' competitors, there are significant positive trends in the competitiveness of domestic product.

Table 3. Participation of Southeast European countries in foreign trade in wine in 2019 (in \$ 000)

\begin{tabular}{|l|c|c|}
\hline SEE countries & Export & Import \\
\hline Albania & 1,104 & 11,600 \\
\hline Bosnia and Herzegovina & 4,023 & 19,202 \\
\hline Northern Macedonia & 51,831 & 1,099 \\
\hline Serbia & 20,895 & 30,804 \\
\hline Montenegro & 13,332 & 8,493 \\
\hline Total SEE countries & $\mathbf{9 1 , 1 8 5}$ & $\mathbf{7 1 , 1 9 8}$ \\
\hline
\end{tabular}

Source: World Trade Center

The countries of Southeast Europe are wine exporters primarily thanks to Northern Macedonia and Montenegro. This indicator speaks enough on the competitiveness of wine producers, where the Republic of Serbia ranks only third in the region, which classifies it as a net importer of wine.

\section{Wine quality as a factor of competitiveness}

Numerous factors determine the quality of wine, and the variability of quality limits the possibility of participating in the international market. Wines with a geographical indication create a belief among consumers that these are products of specific quality and taste, for which they are willing to pay a higher price (Đekić and Jovanović, 2010). Quality, which is confirmed by geographical, ecological or some other label, is completely in trend, so consumers are increasingly buying such products (Živkov et al., 2012). In the last decade, wines have been protected through a geographical indication, which contributes to the development of viticulture and the wine industry, as well as the image of certain geographical areas. Branding through a geographical indication directs the customer to a specific area, as well as the specifics of individual wines, which allows the producer to gain the trust of customers, achieve better placement and higher prices. Dogan and Gokovali (2012) point out that the geographical indication 
helps small producers to differentiate their indigenous product and thus achieve a competitive advantage.

In theory and practice, the importance of non-price factors of competitiveness is emphasized and there is no divergence of opinions (Gagović, 2016). The basic question that arises is how to measure competitiveness by quality.

The quality indicator in foreign trade is the unit value of the product (UV value), defined by the ratio of the value of exports, i.e. imports, to a unit of measure (usually kilograms). Using this indicator, it is possible to compare it with other countries, and thus determine the relative position (Branković and Baranenko, 2014).

The higher unit value of exports indicates the fact that a specific country (Božić and Nikolić, 2016):

- offers higher quality products, i.e. products with a higher content of added value;

- $\quad$ specializes in high priced products;

- sells an identical product at a higher price, due to higher managerial and marketing skills of exporters.

For the period 2010-2019, the average UV export of wine from the Republic of Serbia is $1.36 \$ / 1$, while for imports it amounts to $1.25 \$ / 1$ (Table 1). This indicator shows that, on average, lower quality wine is imported rather than it is exported.

The value of wine exports grew in the observed period and recorded the maximum value in 2019 (\$21,610.00) (Table 1), which instills optimism that the growth trend of exports will continue. The decline in the value of exports after 2014 is probably the result of unfavourable weather conditions, i.e. lower production in that year.

The value of wine imports in the observed period (2010-2019) was the lowest in 2015 $(\$ 28,351,200.00)$ (Table 1), but significant growth in imports was achieved again in 2016. This could be explained by the fact that cheaper wine is imported, given the relatively higher quantities in imports and the slightly lower average price in relation to the export price.

Research shows that the correlation between the GDP and exports is somewhat smaller if exports grow due to low costs, and it is higher if exports grow due to higher quality (Stojanović, 2018). Đurić (2015) points out that in the long run, domestic producers cannot count on competitiveness with low costs, based on cheap raw materials and labor. In this context, only increasing and maintaining wine quality can lead to higher exports.

The competitiveness in quality exists if higher product prices lead to higher exports (price elasticity), which is the case with our wine. The price in the observed period increased from $\$ 1.16$ from 2010 to $\$ 1.55$ in 2019 , and at the same time there was an increase in wine exports. 


\section{Price competitiveness of domestic wines}

Price competitiveness prevails if, while maintaining lower prices, exports increase. Based on the comparison of price and quantity movements, changes that have occurred over time can be analyzed. Export markets can be segmented into those dominated by quality, on the one hand, and markets dominated by prices, on the other (Vehapi, 2018). Thus e.g. in markets that seek quality, we will offer high quality, while in those markets where price is important, we will offer a product in various price categories, favoring a slightly lower price. Considering that the export of wine to the EU market, where quality is quite important, is not easy and the quantities in question are many times smaller than the import quantities, we can conclude that our wines are not competitive on the EU market in terms of quality. We also export wines to the EU at a significantly lower price than we import. Let's just give an example from 2019, when we exported wine at an average price of \$ 1.66/1 (1,496,700 liters), and imported \$3.37/1 (3,074.70 liters).

So, one of the reasons that limits the greater realization of wine is the price. Given the relatively lower standard of the domestic population, the high price, regardless of the fact that it implies higher quality, can be an obstacle to greater purchase of these products, and thus to the growth of competitiveness of producers. This is less characteristic of export markets.

In addition, the success of a low prices strategy, i.e. lower production costs, can produce results only if wine producers can maintain low product prices in the long run (Aguglia et al., 2010; Zarić et al., 2014). Competitive strategy focused exclusively on low prices gives good results only if wineries define target group of customers, for whom price is the most important feature of the product and who are willing to sacrifice all other attributes, such as quality, packaging, taste, geographical origin etc. (Tanwar, 2013; Zarić et al., 2014).

Competitiveness can be expressed by the ratio of quality and price of a particular product. The higher the coefficient, the more competitive the product will be (Đekić and Jovanović, 2010).

\section{Conclusion}

The main reasons for the slower development of the wine sector, which determine the low competitiveness and productivity of wine producers, are the lack of economies of scale, modern equipment and technology. Wine production is mainly based on family wineries of small and medium capacity, most of which do not use modern technologies for wine processing and storage, which makes it difficult to achieve and maintain a desirable competitive position. In addition, the analysis of the competitiveness of domestic wines has shown:

By way of monitoring the so-called revealed comparative advantages in wine production a slight increase in the competitiveness of the wine industry has been shown, especially in recent times, because the negative foreign trade balance of wine decreased for the 
observed period 2010 - 2019. Data on foreign trade in wine show that in the observed period there has been an increase in exports at an average annual rate of of $5.65 \%$, while imports fell at a rate of $0.96 \%$.

- We analyzed the quality of wine as a factor of competitiveness through the unit value of the product (UV). For the observed period, the average UV export of wine is 1.36 $\$ / 1$, while for wine imports it amounts to $1.25 \$ / 1$. This indicator shows that on average, wine of slightly lower quality is imported, compared to exports. Given that the export of wine to the EU market is quite modest, where quality is sought, we can assess that our wines quality is not competitive in that market. As all relevant research shows that exports are growing thanks to higher quality, further increasing and maintaining wine quality is a priority.

- Price competitiveness exists when a rise in product prices leads to higher exports, as is the case with our wine. If we focus on the EU market again, then we certainly do not have price competitiveness, because export prices are significantly lower than import prices of wine in the period after 2013.

Strengthening the capacity of the wine sector, i.e. raising the competitiveness of wine producers, includes:

- agricultural policy measures that will encourage the introduction of modern equipment and technology in the production and processing of grapes, as a key factor in ensuring the quality of wine and achieving better economics in business, as well as the dissemination of the latest scientific knowledge;

- marketing activities, and especially branding of domestic wines through the introduction of geographical indications and on that basis better market positioning.

In addition, in order to increase the competitiveness of wine capacities, it is necessary to harmonize the interest of the public and private sector, define and implement a strategy to strengthen the competitiveness of the wine industry, which will focus on investment in research and development, support for small producers through a system of subsidies, education, association of producers and financing of production. Quality standardization has been recognized as an important factor in the growth of the competitiveness of the wine sector. With adequate marketing and strengthening the competitiveness of domestic wineries, significant benefits can be expected in the future.

Without stronger state support, no significant growth in the competitiveness of the wine industry can be expected. Greater support in terms of improving the business climate, cofinancing projects, introducing innovations is expected in the future period from the agricultural budget, but also through EU technical assistance programs in the accession process.

Since the number of wineries in the Republic of Serbia has recently increased, it is to be expected that the production of grapes and wine, as well as exports, will increase, and thus achieve significantly greater effects. 


\section{Acknowledgements}

Paper is a part of research within the project no. 680-00-00071/2020-02, Improving the competitiveness of the wine sector in Serbia - EduNaWi ${ }^{6}$, which is financed by Ministry of Agriculture, Forestry and Water Management, Republic of Serbia.

\section{Conflict of interests}

The authors declare no conflict of interest.

\section{References}

1. Aguglia, L., De Santis, F., \& Salvioni, C. (2010). Direct Selling: A Marketing Strategy to Shorten Distances between Production and Consumption. $9^{\text {th }}$ European IFSA Symposium, 4-7 July 2010. Vienna. p. 1701-1711.

2. Božić,D., \&Nikolić, M. M.(2016). Characteristics of Serbian foreign trade of agricultural and food products. Marketing, 47 (4), 293-304. doi:10.5937/markt1604293B

3. Branković, A., \& Baranenko, E. (2014). Analiza spoljnotrgovinske razmene prerađivačke industrije. U: Deindustrijalizacija u Srbiji:mogućnosti revitalizacije industrijskog sektora. Institut ekonomskih nauka, Beogradska bankarska akademija, Fakultet za bankarstvo, osiguranje i finansije, Beograd, 566-582. [in English: Branković, A., Baranenko, E. (2014). Foreign Exchange Analysis of Processing Industry. In Deindustrialization in Serbia: possibilities of revitalization of the industrial sector. Institute of Economic Sciences, Belgrade Banking Academy, Faculty of Banking, Insurance and Finance, Belgrade, 566-582].

4. Brščić, K., Oplanić, M., \& Miladinović. N. (2010). Promocija u funkciji razvoja vinarskog sektora u Istri. Agronomski glasnik, 4-5, 277-288. [in English: Brščić, K., Oplanić, M., \& Miladinović. N. (2010). Promotion as a Tool of Development of Wine Sector in Istria Region. Agronomy journal, 4-5, 277-288.].

5. Crampton, P. (2002). Striking the Right Balance between Competition and Regulation: The Key is learning from our mistakes. APEC-OECD Co-operative Initiative on Regulatory Reform.

6. Cvijanović, D., \& Ignjatijević, S. (2020). International Competitiveness of Niche Agricultural Products: Case of Honey Production in Serbia. In V. Erokhin, \& T. Gao (Eds.), Handbook of Research on Globalized Agricultural Trade and New Challenges for Food Security (pp. 443-464). Hershey, PA: IGI Global. doi:10.4018/978-1-7998-1042-1.ch022

7. Cvijanović, D., Ignjatijević, S., Vapa Tankosić, J. \& Cvijanović, V. (2020) Do Local Food Products Contribute to Sustainable Economic Development? Sustainability, 12 (5), 2847; doi:10.3390/su12072847

8. Cvjetković, M., \& Ilić, D. (2015). Kvalitet u funkciji unapređenja konkurentnosti domaćih preduzeća. Ekonomski izazovi, 4, (7), 48-63. [in English: Cvjetković, M., \& Ilić, D. (2015). Quality in the function of improving competitiveness of domestic enterprises. Economic Challenges, 4, (7), 48-63.]. 
9. Đekić, S., \& Jovanović, S. (2010). Orijentacija poljoprivrede Srbije ka konkurentnosti kvalitetom. Škola biznisa, 4, 24-31. doi: 10.5937/skolbiz2-28037 [in English: Đekić, S., \& Jovanović, S. (2010). Orientation of Serbian Agriculture to Competitiveness with Quality. School of Business, 4, 24-31.].

10. Denda, S., \& Denda, B. (2016). Proizvodnja i robna razmena grožđa i vina: stanje u svetu i Srbiji (šumadijski region). Agroekonomika, 45 (70), 81-93. [in English: Denda, S., \& Denda, B. (2016). Production and foreign trade of grapes and wine: situation in the world and Serbia (Šumadija region). Agroeconomics, 45 (70), 81-93.]

11. Dogan, B., \& Gokovali, U. (2012). Geographical indications: the aspects of rural development and marketing through the traditional products. Procedia - Social and Behavioral Sciences, 62, 761-765. doi: doi.org/10.1016/j.sbspro.2012.09.128

12. Dresch, A., Collatto, D. C., \& Lacerda, D. P. (2018). Theoretical understanding between competitiveness and productivity: firm level. Ingeniería y competitividad, 20 (2), 69-86. doi: 10.25100/iyc.v20i1.5897

13. Đurić, K. (2015). Ekonomika poljoprivrede - praktikum, Poljoprivredni fakultet, Novi Sad. [in English: Đurić, K. (2015). Agricultural economics - practicum, Faculty of Agriculture, Novi Sad.]

14. Erdelji, T., \& Lajko, B. (2015). Strategija razvoja vojvođanskog vinarstva u globalnoj ekonomskoj sferi. Anali Ekonomskog fakulteta u Subotici, 51 (34), 289308. [in English: Erdelji, T., \& Lajko, B. (2015). The Development Strategy of the Wine Industry of Vojvodina in the Global Economic Sphere. The Annals of the Faculty of Economics in Subotica, 51 (34), 289-308.]

15. Espejel, J., Fandos Herrera, C., \& Flavián, C. (2008). Consumer satisfaction. A key factor of consumer loyalty and buying intention of a PDO food product. British Food Journal, 110 (9), 865-881. doi: 10.1108/00070700810900585

16. Gagović, N. (2016). Determinante rasta izvoza i analiza mogućnosti povećanja izvoza Srbije. Doktorska disertacija, Univerzitet Singidunum, Fakultet za ekonomiju, finansije i administraciju - FEFA. [in English: Gagović, N. (2016). Determinantes of Export Growth and Analysis of Possibilities for Serbian Exports Enlargement. Doctoral dissertation. Singidunum University, Faculty of Economics, Finance and Administration - FEFA].

17. Ignjatijević, S., \& Cvijanović, D. (2017). Exploring the global competitiveness of agri-food sectors and Serbia's dominant presence: emerging research and opportunities, Publisher: IGI Global, Hershey, PA: Business Science Reference (an imprint of IGI Global), ISBN: 978-1-5225-2762-6, 1-193

18. Ignjatijević, S., Milojević, I., \& Andžić, R. (2018). Economic analysis of exporting Serbian honey. International Food and Agribusiness Management Review, 21 (7), 929-944. doi.org/10.22434/IFAMR2017.0050

19. International Trade Center Trade Map, http://www.trademap.org/ 
20. Jakšić, D., Ivanišević, D., Đokić, V., \& Brbaklić-Tepavac, M. (2015). Vinski atlas. Republički Zavod za statistiku, Beograd. [in English: Jakšić, D., Ivanišević, D., Đokić, V., \& Brbaklić-Tepavac, M. (2015). Vine atlas. The Statistical Office of the Republic of Serbia, Belgrade].

21. Jević, J., Čerović, S., Jević, G., \& Čavlin, M. (2019). Accessible tourism as the factor in creating the image of Serbian wineries as a segment of agritourism supply. Economics of Agriculture, 66 (4), 1157-1171. doi: https://doi.org/10.5937/ ekoPolj1904157J

22. Jovanovic, D., Bela, M., \& Andjelkovic, A. (2015). Vinarije i putevi vina kao sredstvo za razvoj agroturizma u Srbiji. Turističko poslovanje, 15, 87-93. doi: 10.5937/TurPos1515087J [in English: Jovanovic, D., Bela, M., \& Andjelkovic, A. (2015). Wineries and wine routes as a tool for the development of agritourism in Serbia. Business of Tourism, 15, 87-93.].

23. Leković, V. (2016). Institucionalna determinisanost konkurentnosti nacionalne ekonomije: pouke za Republiku Srbiju, u: Unapređenje konkurentnosti privrede Republike Srbije, redaktori Marinković, V., Janjić, V., Mićić, V., Ekonomski fakultet, Kragujevac. [in English: Leković, V. (2016). Institutional Determination of the Competitiveness of the National Economy: Lessons for the Republic of Serbia. in Improving the competitiveness of the economy of the Republic of Serbia. eds. Marinković, V., Janjić, V., Mićić, V., Faculty of Economics, Kragujevac].

24. Marinković, V., Janjić, V., \& Mićić, V. (2016). Unapređenje konkurentnosti privrede Republike Srbije. Ekonomski fakultet, Univerzitet u Kragujevcu. [in English: Marinković, V., Janjić, V., \& Mićić, V. (2016). Improving the competitiveness of the economy of the Republic of Serbia. Faculty of Economics, University in Kragujevac].

25. Ministarstvo poljoprivrede, šumarstva i vodoprivrede Republike Srbije - MPŠV RS (2019). IPARD program za Republiku Srbiju za period 2014-2020. godine. [in English: The Ministry of Agriculture, Forestry and Water Economy of the Republic of Serbia (2019). IPARD Programme of Republic of Serbia for the period of 2014-2020]. Available online: http://www.minpolj.gov.rs/ipard-program-20142020/?script=lat (22 July 2020)

26. Mosurović-Ružičić, M., Semenčenko, D., \& Kutlača, Đ. (2015). Inovaciona infrastruktura za transfer i difuziju tehnologija u Srbiji. Marketing, 46 (1), 3646. [in English: Mosurović-Ružičić, M., Semenčenko, D., \& Kutlača, Đ. (2015). Innovation Infrastructure for Techonlogy Transfer and Difusion in Serbia. Marketing, 46 (1), 36-46].

27. Paraušić, V., \& Cvijanović, J. (2014). Konkurentnost agroprivrede Srbije: Klasteri u funkciji održive regionalne konkurentnosti. Institut za ekonomiku poljoprivrede, Beograd. [in English: Paraušić, V., \& Cvijanović, J. (2014). Competitiveness of Serbian agriculture: Clusters in the function of sustainable regional competitiveness. Institute of Agricultural Economics, Belgrade]. 
28. Pivac, T. (2008). „Vinogradarstvo $i$ vinarstvo u turističkoj ponudi Vojvodine“, Doktorska disertacija, Prirodno matematički fakultet, Novi Sad. [in English: Pivac, T. (2008). Viticulture and Wine Production in the Tourism Offer of Vojvodina Province. Doctoral dissertation. Faculty of Sciences, Novi Sad].

29. Pivac, T. (2012). Vinski turizam Vojvodine, monografija, Prirodno-matematički fakultet, Novi Sad. [in English: Pivac, T. (2012). Wine Tourism of Vojvodina, monograph, Faculty of Sciences, Novi Sad].

30. Pivac, T., Đuranović, T., \& Košić, K. (2015). Značaj vinskih manifestacija za turizam Vojvodine. Agroekonomika, 44 (67), 51-56. [in English: Pivac, T., Đuranović, T., \& Košić, K. (2015). The Importance of Wine Events for Tourism in Vojvodina. Agroeconomics, 44 (67), 51-56.].

31. Porter, M. (1990). The Competitive Advantage of Nations, The Free Press A division of Macmillan, Inc., New York.

32. Prodanović, R., Brkić, I., Škrbić, S., Đurić, K., \& Bošković, J. (2020). Strengthening the capacity of the wine sector in the service of sustainable rural development of the Republic of Serbia, Journal of Agronomy, Technology and Engineering Management, 3 (5), 489-498.

33. Šegrt, S., \& Kolarski, I. (2015). Uslovi egzistencije preduzeća. Oditor, 11, 32-41. [in English: Šegrt, S., \& Kolarski, I. (2015). Conditions of Existence of Companies. Oditor, 11, 32-41.].

34. Statistical Office of the Republic of Serbia - SORS, https://data.stat.gov.rs/

35. Stojanović, D. M. (2018). Strane direktne investicije, izvoz i ekonomski rast u Srbiji. Poslovna ekonomija, 12 (1), 54-72. doi: 10.5937/poseko13-16543 [in English: Foreign direct investments, export and economic growth in the Serbia. Business Economics, 12 (1), 54-72.].

36. Strategija naučnog i tehnološkog razvoja Republike Srbije za period od 2021. do 2025. godine - Moć znanja, [in English: Strategies of scientific and technological development of the Republic of Serbia for the period from 2021 to 2025 - The power of knowledge]. Available online (02 Jun 2021): http://www.mpn.gov.rs/wpcontent/uploads/2020/12/Predlog-Strategije-naucnog-i-tehnoloskog-razvoja-javarasprava.pdf

37. Strategija zapošljavanja u Republici za period od 2021. do 2026. godine, "Službeni glasnik RS", br. 18 od 1. marta 2021, br. 36 od 9. aprila 2021, [in English: Employment Strategy of the Republic of Serbia for the period from 2021 to 2026, Official Gazette of Republic of Serbia, no. 18 of March 1, 2021, no. 36 of April 9, 2021]. Available online (02 Jun 2021): http://www.nsz.gov.rs/live/dokumenti/ strategija_zapo_ljavanja_u_rs_za_period_2021._do_2026._godine.cid74576

38. Tanwar, R. (2013). Porter's generic competitive strategies. Journal of business and management, 15 (1), 11-17. 
39. USAID (2019). Anketa 1000 preduzeća 2019 Rezime. USAID-ov projekat saradnje za ekonomski razvoj. [in English: USAID (2019). Survey of 1,000 companies 2019 Summary. USAID Economic Development Cooperation Project]. Available at (01 Jun 2021): https://saradnja.rs/wp-content/uploads/2019/09/Anketa-1000preduze\%C4\%87a-2019_Rezime.pdf

40. Vehapi, S. (2018). Segmentacija i pozicioniranje na tržištu organske hrane. Naučne publikacije Državnog univerziteta u Novom Pazaru. Serija B, Društvene \& humanističke nauke, 1 (1), 47-59. doi:10.5937/NPDUNP1801047V [in English: Vehapi, S. (2018). Segmentation and positioning on the organic food market. Scientific Publications of the State University of Novi Pazar. Series B: Social Sciences and Humanities, 1 (1), 47-59.].

41. Vlahović, B., Puškarić, A., \& Užar, D. (2017). Savremeni trendovi na tržištu vina. Poljoprivredni fakultet, Novi Sad. [in English: Vlahović, B., Puškarić, A., \& Užar, D. (2017). Contemporary trends in the wine market. Faculty of Agriculture, Novi Sad].

42. Vukajlović, Đ., \& Ćurčić, N. (2016). Ocena faktora konkurentnosti i inovativnosti u cilju ostvarivanja tržišnog učešća. Ekonomija: teorija i praksa, 9 (3), 35-54. [in English: Vukajlović, Đ., \& Ćurčić, N. (2016). The evaluation of competitiveness and innovation factors in order to increase market share. Economics - theory and practice, 9 (3), 35-54.]

43. Yigezu, Y. A., Mugera, A., El-Shater, T., Aw-Hassan, A., Piggin, C., Haddad, A., ... \& Loss, S. (2018). Enhancing adoption of agricultural technologies requiring high initial investment among smallholders. Technological Forecasting and Social Change, 134, 199-206. doi.org/10.1016/j.techfore.2018.06.006

44. Zaric, V., Vasiljević, Z., Nedić, N., \& Petković, D. (2013). The marketing strategies of Serbian honey producers. APSTRACT: Applied Studies in Agribusiness and Commerce, 7 (1033-2016-84237), 27-31. doi:10.19041/Apstract/2013/2-3/4

45. Zdravković, M. (2020). Rekordna vrednost izvoza vina u 2019. i površine pod vinogradima u Srbiji. [in English: Zdravković, M. (2020). Record value of wine exports in 2019 and the area under vineyards in Serbia.]. Available at (29 October 2020): https://www.makroekonomija.org/0-miroslav-zdravkovic/rekordna-vrednostizvoza-vina-u-2019-i-povrsine-pod-vinogradima-u-srbiji/

46. Živkov, G., Obućina, B., Teofilović, N., Bernardoni, P., Dulić-Marković, I., Bardić, D., \& Božić, M. (2012). Analiza trendova u proizvodnji i trgovini poljoprivrednih proizvoda iz Vojvodine u odnosu na proizvodnju i trgovinu u Srbiji, regionu, EU $i$ svetu. SEEDEV, Za Program: „Fond za promociju izvoza poljoprivrednih proizvoda“" - APF br. JNMV 19/2012. [in English: Živkov, G., Obućina, B., Teofilović, N., Bernardoni, P., Dulić-Marković, I., Bardić, D., \& Božić, M. (2012). Analysis of trends in production and trade of agricultural products from Vojvodina in relation to production and trade in Serbia, the region, the EU and the world. SEEDEV, For the Program: "Agricultural Export Promotion Fund" - APF number JNMV 19/2012. 